\title{
SUCCESS ANALYSIS OF KITABISA MOBLIE APPLICATION INFORMATION SYSTEM BY USING DELONE AND MCLEAN MODELS
}

\author{
Hafiz Noval Hasany Aditya1; Nurmalasari²; Hendri ${ }^{3}$ \\ 1, 2 Information Systems; ${ }^{3}$ Informatics Engineering \\ STMIK Nusa Mandiri, Jakarta, Indonesia \\ 11hafiznov0711@nusamandiri.ac.id; 2nurmalasari.nmr@nusamandiri.ac.id, \\ 33endri.hed@nusamandiri.ac.id
}

\begin{abstract}
KitaBisa is a place to donate and raise funds online at KitaBisa, the public can raise funds for a variety of things that they do or donate for things they want to help. Measuring the success of the KitaC mobile application can use the DeLone and McLean model, it is known that variables that have a significant relationship include Service Quality against User Statisfaction with a t-statistic value of 2.893, System Quality for Users (Use) with a t-statistic value of 10,204, and User Satisfaction of the Net Benefit with a t-statistic value of 3,680. In accordance with the hypothesis testing that user satisfaction with the KitaBisa mobile application as a forum for donating online has been proven by influencing User Satisfaction with the Net Benefit as a whole or it means the user has felt the benefits of the KitaBisa mobile application.
\end{abstract}

Keywords: DeLone dan McLean, Information System Success, KitaBisa.

Intisari-KitaBisa adalah wadah untuk berdonasi dan menggalang dana secara Online di KitaBisa, masyarakat bisa menggalang dana untuk beragam hal yang mereka maupun berdonasi untuk hal yang ingin mereka bantu. Pengukuran kesuksesan aplikasi mobile KitaBisa menggunakan model DeLone dan McLean telah diketahui variabel yang memiliki hubungan signifikan antara lain Kualitas Pelayanan (Service Quality) terhadap Kepuasaan Penggunaan (User Statisfaction) dengan nilai $t$ statistic 2,893, Kualitas Sistem (System Quality) terhadap Pengguna (Use) dengan nilai t-statistic 10,204, serta Kepuasan Pengguna (User Statisfaction) terhadap Hasil atau Manfaat Bersih (Net Benefit) dengan nilai t-statistic 3,680. Sesuai dengan pengujian hipotesis bahwa kepuasan pengguna terhadap aplikasi mobile KitaBisa sebagai wadah untuk berdonasi secara online telah terbukti dengan berpengaruhnya Kepuasan Pengguna (User Statisfaction) terhadap Hasil atau Manfaat Bersih (Net Benefit) secara keseluruhan atau berarti pengguna telah merasakaan manfaat adanya aplikasi mobile KitaBisa.

Kata Kunci: DeLone dan McLean, Kesuksesan Sistem Informasi, KitaBisa.

\section{INTRODUCTION}

Internet technology innovations that are progressing can be utilized to raise social donations, humanity, and handling victims of natural disasters. There are many internet-based startups (startups) that use crowdfunding systems to raise funds from the public(I.Chailis, 2019). The donation-based crowdfunding model used for fundraising has proven to be successful in raising aid funds (Nugroho \& Rachmaniyah, 2019) especially in the event of natural disasters and other emergencies.

Obstacles to accessing information, education, and literacy via the internet related to knowledge and understanding of financial products are one of the causes of the low participation of Indonesians in crowdfunding, resulting in slow crowdfunding development in Indonesia (Nugroho \& Rachmaniyah, 2019).

KitaBisa is a forum to donate and raise funds online at KitaBisa, the public can raise funds for various things as they are and contribute to the things they want to help. (Sitanggang, 2018)

Until 2018, there are more than 1 million donors and 500 million (kitabisa.com, 2018) funds have been collected with more and more donors many comments and input related to the KitaBisa mobile application, based on complaints and comments on the KitaBisa application on Google Play, the 2017-2019 period tends to lead to quality problems system, service usage, user satisfaction, and individual impact felt by users. Although the quality provided is higher, it will affect the high level of user satisfaction. And service quality has a positive and significant impact on user satisfaction (Amalina \& Helni Mutiarsih Jumhur, 2018).

An information system can be relied upon if it has a good quality system and can provide satisfaction to the wearer. Because the better the perception of the quality of the system will increase user satisfaction (Aziati, 2020)

Based on the description in the background of the problem above, the purpose of this study is to measure the level of satisfaction of users of the 
KitaBisa mobile application and measure the success rate of the KitaBisa mobile application donation system. By measuring the KitaBisa mobile application we can find out the users who benefit from the KitaBisa mobile app as an online donation drive application.

In this study, the success model of the Delone and Mclean model uses variables of system quality, information quality, service quality, users, user satisfaction, and final results. This research was conducted by analyzing the Structural Equation Model (SEM) to measure the success rate of the KitaBisa mobile application. The stages to analyze are by testing the Outer Model, Inner Model, and Bootstrapping.

\section{MATERIALS AND METHODS} systems on the surface for the first time in 1992. ifhplenteistationryphase which includes website updated in 2003(Saputro et al., 2016).

From the updated model there are six variables, (Wisudiawan, 2015) namely:

1. The quality of the system used to measure the quality of the information technology system itself.

2. Information Quality (Information Quality) used to measure the quality of the output of the information system.

3. Service quality (service quality) provided by the information system developer.

4. Usage (Use) is the use of the output from the system by the recipient/user and interest to use (intention to use) as an alternative to using.

5. User Satisfaction is the user's response to the use of information systems. 6 . Net benefits are the effects of information on users and the effect of information on organizations to improve knowledge and communication.

Based on the DeLone and McLean model variables as above, we get a hypothesis like the following:

H1a: The quality of the system will have a positive and significant effect on users (used);

H1b: The quality of the system will have a positive and significant effect on user satisfaction (satisfaction of use);

H2a: Information quality will have a positive and significant effect on system usage (usage);

$\mathrm{H} 2 \mathrm{~b}$ : Kualitas informasi (information quality) akan berpengaruh positif dan signifikan terhadap kepuasan pengguna (user satisfaction);

H3a: Service quality will have a positive and significant effect on system usage (usage);

H3b: Service quality will have a positive and significant effect on user satisfaction; Then if the quality of the system (quality of the system), quality of information (information system) and service (quality of service) has been obtained, then the next will find out whether there is a relationship between intention to use, user satisfaction and network. the benefits.

H4a: System usage (usage) will have a positive and significant effect on user satisfaction (satisfaction of use) and vice versa;

H4b: System usage (usage) will have a positive and significant effect on net benefits (net income);

H5a: User satisfaction will have a positive and significant effect on net benefits;

This study has 3 stages of completion. The first is the initial stage which contains problem identification, literature study, model selection, analysis, website success analysis. In the third stage, conclusions are drawn containing the results of the analysis and discussion as well as providing recommendations and making research reports.

(Arifin \& Pratolo, 2012) Descriptive analysis was conducted to determine the characteristics of the respondents. In this study, the characteristics of the respondents surveyed were grouped into gender, age, and domicile. It also analyzes the characteristics of the results of the respondents' answers on the questionnaire.

\section{RESULTS AND DISCUSSION}

In processing research data that has been obtained through a questionnaire, the author will conduct an SEM analysis using the help of smartPLS 3 software (version 3.0). Analysis using smartPLS consists of two submodels, namely the measurement model (measurement model) or often called the outer model, and the structural model (structural model), or often called the inner model. The following is a test of the measurement model as well as the structural model:

1. Analysis of Measurement Models (External Models)

At this stage, the test will be carried out to determine whether the measurements used in this study are valid and reliable or not.

a. Convergent Validity Test

Convergence Validity or convergent validity aims to determine the validity of each relationship between the indicator and its latent variable. In this study, the authors used a factor loading limit of 0.6 , which means the indicator would be considered valid if it had an external loading value of more than 0.6. 


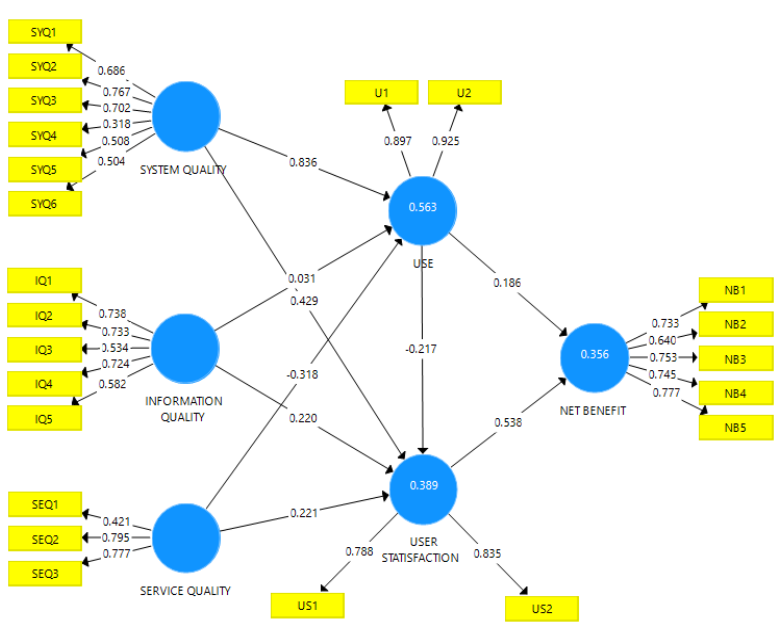

Source: (Aditya et al., 2019)

Figure 1. Early Models Structural Equation Models

(SEM)

Figure 1 shows that the indicators SYQ4, SYQ5, SYQ6, IQ3, and SEQ1 have low validity because they do not comply with the requirements ie above 0.6. These indicators must be removed/dropped from the model before testing at a later stage. The model after falling on the indicator that has a loading factor value below 0.6 is as follows:

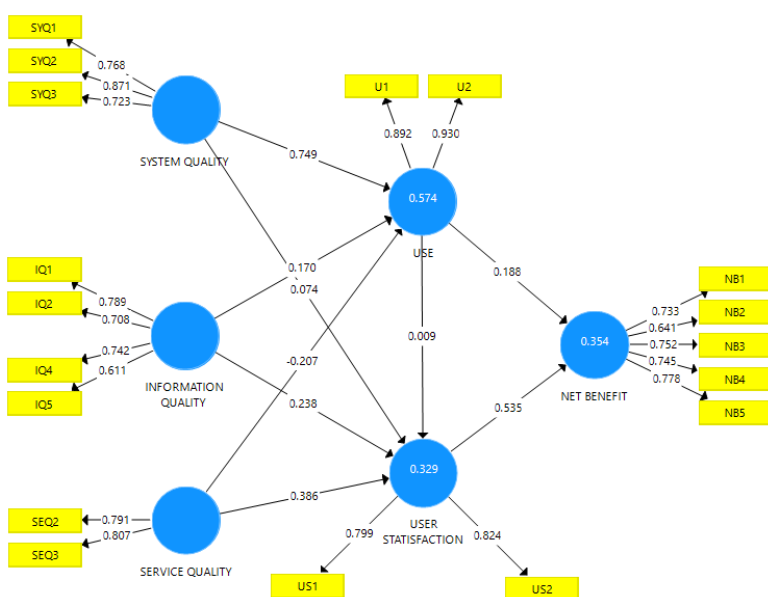

Source: (Aditya et al., 2019)

Figure 2. The Best Stuctural Equation Model (SEM).

Figure 2 shows that all indicators have met the requirements having a loading factor value above 0.6 and it can be stated that in this study all indicators already have a good level of validity so that the next testing phase can be carried out.

b. Average Variance Extracted Test (AVE)

Testing at this stage aims to determine the level of convergent validity. Each variable must have a value of AVE $\geq 0.5$ to be able to meet AVE or good convergent validity.

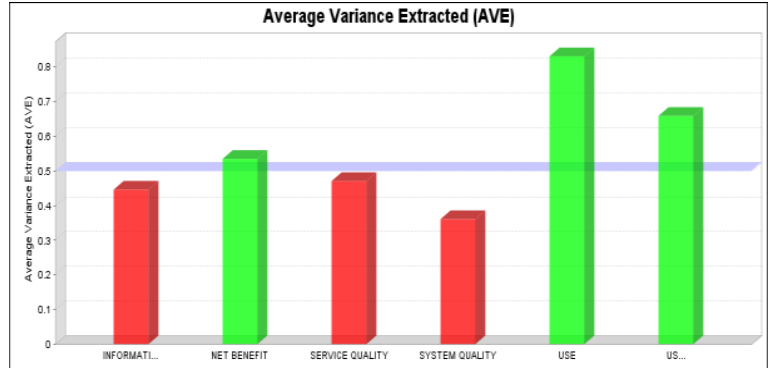

Source: (Aditya et al., 2019)

Figure 3. Results of Initial AVE Value

Figure 3 there are still variables that have AVE values below 0.5 , namely the variable Information Quality, Service Quality, and System Quality, while the other variables have shown good convergent validity. For Information Quality, Service Quality, and System Quality variables, dropping must be done on several indicators so that these variables can meet the requirements of AVE value AVE 0.5.

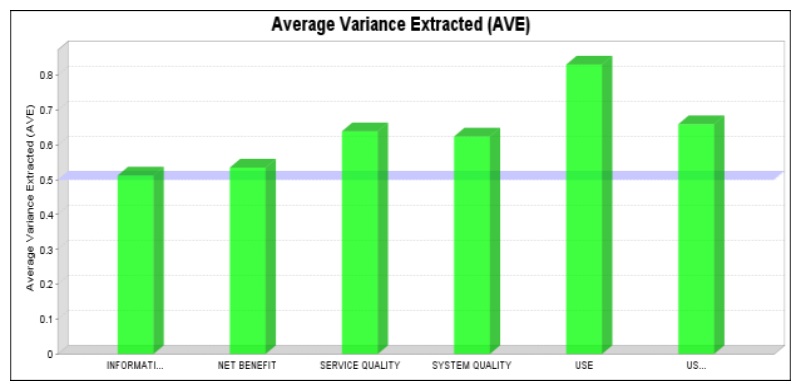

Source: (Aditya et al., 2019)

Figure 4. Best AVE Value Results

After dropping several indicators whose variables have AVE values below 0.5 , then at 4 shows that all variables have shown good convergent validity. The following is the AVE value for each variable, seen in table 1 below.:

Table 1 Details of AVE Value for Each Variable

\begin{tabular}{cc}
\hline Variabel & $\begin{array}{c}\text { Average Variance Extracted } \\
\text { (AVE) }\end{array}$ \\
\hline Information Quality & 0,512 \\
\hline Net Benefit & 0,535 \\
\hline Service Quality & 0,638 \\
\hline System Quality & 0,624 \\
\hline Use & 0,830 \\
\hline User Statisfaction & 0,659
\end{tabular}

Source: (Aditya et al., 2019)

c. Discriminant Validity Test

Discriminant validity aims to find out whether the construct has adequate discrimination or not. To find out is to compare the loading value on the variable correlation construct that is greater than the loading factor value to other variables. Following are the results of discriminant validity in the cross-loading value table: 
Table 2 Discriminant Validity Value (Cross Loadings)

\begin{tabular}{|c|c|c|c|c|c|c|}
\hline & Information Quality & Net Benefit & $\begin{array}{l}\text { Service } \\
\text { Quality }\end{array}$ & $\begin{array}{l}\text { System } \\
\text { Quality }\end{array}$ & Use & User Statisfaction \\
\hline IQ1 & 0,789 & 0,337 & 0,288 & 0,412 & 0,419 & 0,253 \\
\hline IQ2 & 0,708 & 0,428 & 0,379 & 0,245 & 0,236 & 0,275 \\
\hline IQ4 & 0,742 & 0,226 & 0,350 & $-0,025$ & 0,070 & 0,332 \\
\hline IQ5 & 0,611 & 0,218 & 0,393 & 0,026 & $-0,044$ & 0,436 \\
\hline NB1 & 0,275 & 0,733 & 0,357 & 0,023 & 0,050 & 0,399 \\
\hline NB2 & 0,449 & 0,641 & 0,361 & 0,282 & 0,333 & 0,259 \\
\hline NB3 & 0,320 & 0,752 & 0,244 & 0,178 & 0,278 & 0,386 \\
\hline NB4 & 0,408 & 0,745 & 0,513 & 0,285 & 0,187 & 0,523 \\
\hline NB5 & 0,128 & 0,778 & 0,340 & 0,245 & 0,171 & 0,446 \\
\hline SEQ2 & 0,348 & 0,267 & 0,791 & 0,244 & 0,086 & 0,410 \\
\hline SEQ3 & 0,431 & 0,532 & 0,807 & 0,218 & 0,062 & 0,428 \\
\hline SYQ1 & 0,188 & 0,244 & 0,313 & 0,768 & 0,568 & 0,099 \\
\hline SYQ2 & 0,244 & 0,246 & 0,250 & 0,871 & 0,626 & 0,259 \\
\hline SYQ3 & 0,161 & 0,179 & 0,122 & 0,723 & 0,538 & 0,230 \\
\hline U1 & 0,111 & 0,127 & $-0,057$ & 0,621 & 0,892 & 0,099 \\
\hline $\mathrm{U} 2$ & 0,337 & 0,351 & 0,200 & 0,707 & 0,930 & 0,186 \\
\hline US1 & 0,392 & 0,364 & 0,495 & 0,261 & 0,152 & 0,799 \\
\hline US2 & 0,337 & 0,549 & 0,360 & 0,152 & 0,110 & 0,824 \\
\hline
\end{tabular}

Source: (Aditya et al., 2019)

Table 2 shows that all indicators have met the requirements of a good discriminant validity test.

d. Composite Reliability Test

Composite reliability test tests the value of the indicator reliability in a construct. In this study, the reliability test aims to assess the extent to which the measurement instruments used in this study are reliable or consistent. The reliability composite value can be categorized as reliable if the value is $\geq$ 0.7 and has a Cronbach alpha value $\geq 0.6$. Following are the results of Cronbach's alpha value and composite reliability:

Table 3. Composite Reliability Test Values

\begin{tabular}{ccc}
\hline Variabel & $\begin{array}{c}\text { Cronbach's } \\
\text { Alpha }\end{array}$ & $\begin{array}{c}\text { Composite } \\
\text { Reliability }\end{array}$ \\
\hline Information Quality & 0,679 & 0,806 \\
\hline Net Benefit & 0,784 & 0,851 \\
\hline Service Quality & 0,434 & 0,779 \\
\hline System Quality & 0,694 & 0,832 \\
\hline Use & 0,797 & 0,907 \\
\hline User Statisfaction & 0,483 & 0,794 \\
\hline
\end{tabular}

Source: (Aditya et al., 2019)

From table 3 it can be concluded that the composite reliability variable is declared reliable because it meets the requirements, namely, for the composite reliability value, all variables have a value of $\geq 0.7$, so that the statement used is stated consistently. While there are alpha Cronbach variables that are not reliable in service quality and user satisfaction because alpha Cronbach's condition has a value of $\geq 0.6$, so statements about service quality and user satisfaction are stated to be inconsistent.
2. Model Struktural Analysis (Inner Model)

The Inner Model stage will describe the relationship between latent variables. Structural model tests can see models that consist of relationships that have been suspected through hypotheses between latent variables in research.

a. R2 analysis

In R2 analysis the independent variable does not have the value of R2 because the variable is not influenced by other variables in the model, so that the value of $\mathrm{R} 2$ is the dependent or endogenous variable, namely Net Benefit, Use, and User Satisfaction Variables. The following are the results of the R-Square test in this study:

Table 4. R-Square Value $\left(\mathrm{R}^{2}\right)$

\begin{tabular}{lc}
\hline \multicolumn{1}{c}{ Variabel } & $\mathbf{R}$ Square $\mathbf{( R}^{\mathbf{2}} \mathbf{)}$ \\
\hline Net Benefit & 0,354 \\
\hline Use & 0,574 \\
\hline User Statisfaction & 0,329 \\
\hline
\end{tabular}

Source: (Aditya et al., 2019)

The table 4 shows that the Net Benefit variable has an R-Square value of 0.354 , which means that the percentage of Usage and User Satisfaction influence is $35.4 \%$ while the remaining $64.6 \%$ is influenced by other factors. For the Net Benefit variable with an R2 of 0.354 , including moderate effects.

The R-Square value of the Usage variable is 0.574 , which means that the percentage of System Quality, Information Quality, and Service Quality is $57.4 \%$ while the remaining $42.6 \%$ is influenced by other parties. For the Use variable with an $\mathrm{R} 2$ value of 0.574 , it has a moderate effect. The R-Square value of the User Satisfaction variable is 0.329 , 
which means that the percentage of System Quality, Information Quality, and Service Quality is $32.9 \%$ while the remaining $67.1 \%$ is influenced by other parties. For the User Satisfaction variable with an R2 value of 0.329 , it has a weak influence.

\section{b. Analysis of F2}

The analysis phase F2 aims to see whether the influence of exogenous (independent) latent variables on endogenous (dependent) latent variables has substantive effects. The following are the results of the F-Square analysis test, like table 5 below:

Table 5. F-Square Value (F2)

\begin{tabular}{|c|c|c|c|c|c|c|}
\hline Variabel & $\begin{array}{l}\text { Inform } \\
\text { ation } \\
\text { Quality }\end{array}$ & $\begin{array}{l}\text { Net } \\
\text { Ben } \\
\text { efit }\end{array}$ & $\begin{array}{c}\text { Serv } \\
\text { ice } \\
\text { Qual } \\
\text { ity }\end{array}$ & $\begin{array}{c}\text { Syst } \\
\text { em } \\
\text { Qual } \\
\text { ity }\end{array}$ & Use & $\begin{array}{c}\text { User } \\
\text { Statisfa } \\
\text { ction }\end{array}$ \\
\hline Information & & & & & 0,0 & \\
\hline Quality & & & & & 51 & 0,060 \\
\hline \multicolumn{7}{|l|}{ Net Benefit } \\
\hline Service & & & & & 0,0 & \\
\hline Quality & & & & & 74 & 0,151 \\
\hline System & & & & & 1,1 & \\
\hline Quality & & & & & 85 & 0,003 \\
\hline \multirow[b]{2}{*}{ Use } & & 0,05 & & & & \\
\hline & & 3 & & & & 0,000 \\
\hline User & & 0,43 & & & & \\
\hline Statisfaction & & 1 & & & & \\
\hline
\end{tabular}

Source: (Aditya et al., 2019)

Based on these tables it can be concluded that:

1) Quality Information Variable has a big effect on the use because it has an F2 value of 0.051 .

2) Information Quality Variable has a big effect on User Statistics because it has an F2 value of 0.060 .

3) Service Quality Variable has a big influence on Usage because it has an F2 value of 0.074 .

4) Service Quality Variable has a big influence on User Satisfaction because it has an F2 value of 0.151 .

5) The System Quality Variable has a big influence on Usage because it has an F2 value of 1.185 .

6) System Quality Variable does not have much effect on User Satisfaction because it has an F2 value of 0.003 .

7) The usage variable has a big influence on Net Benefits because it has an F2 value of 0.053 .

8) Use variable has little or no effect on User Statistics because it has an F2 value of 0,000 .

9) User Statistics Variables have a big influence on Net Benefits because they have an F2 value of 0.431 .

3. Hypothesis Testing (Bootstrapping)

In testing the hypothesis, the author uses a bootstrap analysis on smartPLS. Here is a model obtained from the results of testing the hypothesis with bootstrap, like the picture 5 below:

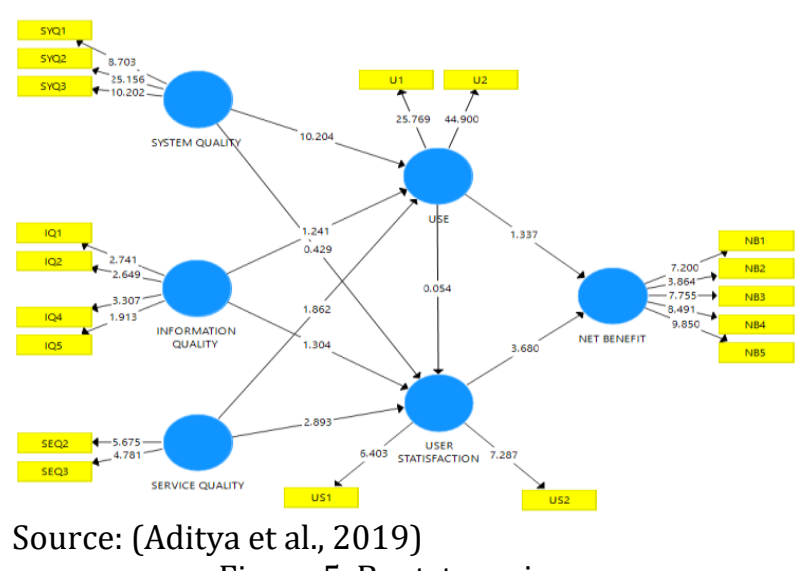

Figure 5. Bootstrapping

Positive or negative effects between variables can be seen in the original sample values. If the original sample value is negative, then both variables have negative effects and vice versa, and if $t$-statistics $\geq 1.96$ or $P$ values $P 0.05$ then have a significant relationship and vice versa. The following are the results of the hypothesis test (path coefficient) in tabular form:

Tabel 6. Hypothesis testing (Path Coefficients)

\begin{tabular}{|c|c|c|c|}
\hline Variabel & $\begin{array}{c}\text { Origin } \\
\text { al } \\
\text { Sampe } \\
\text { I (0) }\end{array}$ & $\begin{array}{c}T \\
\text { Statist }\end{array}$ & $\begin{array}{c}\mathrm{P} \\
\text { Value } \\
\mathrm{s}\end{array}$ \\
\hline Information Quality -> Use & 0,170 & 1,241 & 0,215 \\
\hline $\begin{array}{l}\text { Information Quality -> User } \\
\text { Statisfaction }\end{array}$ & 0,238 & 1,304 & 0,193 \\
\hline Service Quality -> Use & $-0,207$ & 1,862 & 0,063 \\
\hline $\begin{array}{l}\text { Service Quality -> User } \\
\text { Statisfaction }\end{array}$ & 0,386 & 2,893 & 0,004 \\
\hline System Quality -> Use & 0,749 & 10,204 & 0,000 \\
\hline $\begin{array}{l}\text { System Quality -> User } \\
\text { Statisfaction }\end{array}$ & 0,074 & 0,429 & 0,668 \\
\hline Use -> Net Benefit & 0,188 & 1,337 & 0,182 \\
\hline Use -> User Statisfaction & 0,009 & 0,054 & 0,957 \\
\hline User Statisfaction -> Net Benefit & 0,535 & 3,680 & 0,000 \\
\hline
\end{tabular}

Based on the table 6 we get a conclusion like the following:

1) Between the Information Quality variable and the Usage, the variable does not have a significant relationship because the t-statistic value $<1.96$ is 1.241 and has a $\mathrm{P}$ value $>0.05$ which is 0.215 . Both of these variables have positive effects because the original sample value has a positive value of 0.170 .

2) Between the Information Quality variable and the User, the Satisfaction variable does not have a significant relationship because the t-statistic value $<1.96$ is 1.304 and has a $P$ value $>0.05$ which is 0.193 . Both of these variables have a 
positive effect because the original sample value has a positive value of 0.238 .

3) Between Service Quality and Usage variables do not have a significant relationship because the t-statistic value $\leq 1.96$ is 1.862 and has a $\mathrm{P}$ value $\geq 0.05$ which is 0.063 . Both of these variables have a negative effect because the original sample value has a negative value of 0.207.

4) Between the variable Service Quality and User Satisfaction variables have a significant relationship because the t-statistic value $>1.96$ is 2.893 and has a P-value $<0.05$ which is 0.004 . Both of these variables have a positive effect because the original sample value has a positive value of 0.386 .

5) Between the System Quality variable and the Usage, the variable has a significant relationship because the t-statistic value $>1.96$ is 10204 and has a P-value $<0.05$ which is 0.000 . Both of these variables have a positive effect because the original sample value has a positive value of 0.749 .

6) Between the System Quality variable and the User, the Satisfaction variable does not have a significant relationship because the t-statistic value $<1.96$ is 0.429 and has a $P$ value $>0.05$ which is 0.668 . Both of these variables have a positive effect because the original sample value has a positive value of 0.074 .

7) Between the Usage variable and the Net Benefit, the variable does not have a significant relationship because the t-statistic value $<1.96$ is 1.337 and has a $\mathrm{P}$ value $>0.05$ which is 0.182 . Both of these variables have a positive effect because the original sample value has a positive value of 0.188 .

8) Between Usage variables and User, Satisfaction variables do not have a significant relationship because the t-statistic value $\leq 1.96$ is 0.054 and has a P-value $\geq 0.05$ which is 0.957 . Both of these variables have a positive effect because the original sample value has a positive value of 0.009 .

9) Between the User Satisfaction, variable and the Net Benefit variable has a significant relationship because the statistical value of $t \geq$ 1.96 is 3.680 and has a P-value $\leq 0.05$ which is 0.000 . Both of these variables have a positive effect because the original sample value has a positive value of 0.535 .

Based on the results of the SEM analysis that has been done using SmartPLS software, it is known that the answer to the hypothesis has been determined by the author. There are five accepted hypotheses, namely System Quality for Use, System Quality for User Satisfaction, Service Quality for
User Satisfaction, Use for User Satisfaction, and User Satisfaction for Net-Results. As for the rejected hypothesis, there are four hypotheses. If concluded in Table 7 is as follows:

Tabel 7. Conclusion Hypothesis Test

\begin{tabular}{|c|c|}
\hline Hypothesis & Conclusion \\
\hline $\begin{array}{l}\text { H1a : System Quality will have a } \\
\text { positive and significant effect on Users } \\
\text { (Usage). }\end{array}$ & RECEIVED \\
\hline $\begin{array}{l}\text { H1b : System Quality will have a } \\
\text { positive and significant effect on User } \\
\text { Satisfaction. }\end{array}$ & REJECTED \\
\hline $\begin{array}{l}\text { H2a : nformation quality will have a } \\
\text { positive and significant effect on } \\
\text { system usage (Usage). }\end{array}$ & REJECTED \\
\hline $\begin{array}{l}\text { H2b : Information Quality will have a } \\
\text { positive and significant effect on User } \\
\text { Satisfaction. }\end{array}$ & REJECTED \\
\hline $\begin{array}{l}\text { H3a : Service Quality will have a } \\
\text { positive and significant effect on } \\
\text { system usage (Usage). }\end{array}$ & REJECTED \\
\hline $\begin{array}{l}\text { H3b : Service Quality will have a } \\
\text { positive and significant effect on User } \\
\text { Satisfaction. }\end{array}$ & RECEIVED \\
\hline $\begin{array}{l}\text { H4a : System Usage (Usage) will have a } \\
\text { positive and significant effect on User } \\
\text { Satisfaction. }\end{array}$ & REJECTED \\
\hline $\begin{array}{l}\text { H4b : System Usage (Usage) will have a } \\
\text { positive and significant effect on Net } \\
\text { Benefits. }\end{array}$ & REJECTED \\
\hline $\begin{array}{l}\text { H5 : User Satisfaction will have a } \\
\text { positive and significant effect on Net } \\
\text { Benefits. }\end{array}$ & RECEIVED \\
\hline
\end{tabular}

Source : (Aditya et al., 2019)

Explanation of the hypothesis conclusion based on table 7 is as follows:

1) System Quality will have a positive and significant effect on Users (Usage).

Based on the results of the analysis that has been done the hypothesis $\mathrm{H} 1 \mathrm{a}$ has fulfilled the requirements that the $\mathrm{t}$-statistic is $\geq 1.96$ or $\mathrm{P}$ value is $\leq 0.05$. Thus the $\mathrm{H} 1 \mathrm{a}$ hypothesis in this study was accepted. H1a acceptance shows that the high-quality KitaBisa mobile application system will increase user intentions to use the KitaBisa mobile app as a forum for online donations and vice versa.

2) System Quality will have a positive and significant effect on User Satisfaction.

Based on the results of the analysis that has been done the H1b hypothesis does not meet the requirements that the t-statistic is $<1.96$ or the P-value is $>0.05$. Thus the H1b hypothesis in this study was rejected. The $\mathrm{H} 1 \mathrm{~b}$ rejection shows that if the quality of your Kita application system is unreliable, users will feel uncomfortable using the Kita Kita application. This will result in users not satisfied with the existing system in KitaBisa and vice versa.

3) Information quality will have a positive and significant effect on system usage (Usage). 
Based on the results of the analysis that has been done, the $\mathrm{H} 2 \mathrm{a}$ hypothesis does not meet the requirements of the t-statistic value $\leq 1.96$ or the value of P-Value $\geq 0.05$. Thus the $\mathrm{H} 2 \mathrm{a}$ hypothesis in this study was rejected. H2 rejection shows that users of the Kita KitaBisa application cannot assess the quality of information as a reason to always use the application in donating online.

4) Information Quality will have a positive and significant effect on User Satisfaction.

Based on the results of the analysis that has been done the $\mathrm{H} 2 \mathrm{~b}$ hypothesis does not meet the requirements of the t-statistic value $\leq 1.96$ or the value of P-Value $\geq 0.05$. Thus the $\mathrm{H} 2 \mathrm{~b}$ hypothesis in this study was rejected. H2 rejection shows that KitaBisa mobile application users do not make information quality a measure of satisfaction in using KitaBisa mobile applications.

5) Service Quality will have a positive and significant effect on system usage (Usage).

Based on the results of the analysis that has been done hypothesis H3a does not meet the requirements of the t-statistic value $\leq 1.96$ or the value of P-Value $\geq 0.05$. Thus the $\mathrm{H} 3 \mathrm{a}$ hypothesis in this study was rejected. The rejection of $\mathrm{H} 3 \mathrm{a}$ shows that the quality of services provided by the KitaBisa mobile application also does not make an excuse for users to always use the KitaBisa mobile application whenever they donate.

6) Service Quality will have a positive and significant effect on User Satisfaction.

Based on the results of the analysis that has been done the H3b hypothesis has fulfilled the requirements that the t-statistic is $\geq 1.96$ or $\mathrm{P}$ value is $\leq 0.05$. Thus the H3b hypothesis in this study was accepted. The acceptance of $\mathrm{H} 3 \mathrm{~b}$ shows that the high or low quality of services that are in the KitaBisa mobile application will greatly affect the comfort and satisfaction of KitaBisa mobile application users.

7) System usage (Usage) will have a positive and significant effect on User Satisfaction.

Based on the results of the analysis that has been done hypothesis $\mathrm{H} 4 \mathrm{a}$ does not meet the requirements of the t-statistic value $<1.96$ or $\mathrm{P}$ Value $>0.05$. Thus the H4a hypothesis in this study was rejected. The rejection of $\mathrm{H} 4 \mathrm{a}$ shows that users who frequently use the KitaBisa mobile app can mean that users are not satisfied with what is presented in the KitaBisa mobile app and vice versa.

8) System usage (Usage) will have a positive and significant effect on Net Benefits.
Based on the results of the analysis that has been done hypothesis $\mathrm{H} 4 \mathrm{~b}$ does not meet the requirements of the $t$-statistic value $\leq 1.96$ or the $\mathrm{P}$-value is 0.05 . Thus the $\mathrm{H} 4 \mathrm{~b}$ hypothesis in this study was rejected. The rejection of $\mathrm{H} 4 \mathrm{~b}$ shows that users frequently or not use the KitaBisa mobile application. It cannot interpret the presence or absence of benefits provided to users.

9) User Satisfaction will have a positive and significant effect on Net Benefits.

Based on the results of the analysis that has been done, the hypothesis $\mathrm{H} 5$ has met the requirements that the t-statistic is $\geq 1.96$ or the value of $\mathrm{P}$ is $\leq 0.05$. Thus the $\mathrm{H} 5$ hypothesis in this study was accepted. H5 acceptance shows that the satisfaction felt by users affects the high or low benefits obtained by users of the KitaBisa mobile application.

\section{CONCLUSION}

Measuring the success of the mobile application KitaBisa be able to use the DeLone and McLean models, note that variables that have a significant relationship include Service Quality on User Statistics with a t-statistic value of 2.893, System Quality for Users (Usage) with a t-statistic value of 10.204, and User Satisfaction of Net benefits with a t-statistic value of 3,680 . Based on the discussion of research data analysis about the success of the KitaBisa mobile application, the authors conclude following the hypothesis testing that user satisfaction with the KitaBisa mobile application as a forum for online donations has been proven by influencing User Satisfaction. (User Statistics) about Results or Net Benefits (Net Benefits) as a whole or means that users have benefited from the KitaBisa mobile app.

\section{REFERENCE}

Aditya, H. N. H., Nurmalasari, N., \& Hendri, H. (2019). Laporan Akhir Penelitian Mandiri: Analisa Kesuksesaan Sistem Informasi Aplikasi Mobile Kitabisa Dengan Model Delone \& Mclean.

Amalina, N., \& Helni Mutiarsih Jumhur, S. H. (2018). The Influence of User Experience towards User Satisfaction of E-Government Service: a Case Study of GAMPIL Application. International Journal of Scientific and Research Publications (IJSRP), 8(3), 254-259. https://doi.org/10.29322/ijsrp.8.3.2018.p75 38

Arifin, J. F., \& Pratolo, S. (2012). Pengaruh kualitas 
sistem informasi keuangan daerah terhadap kepuasan aparatur pemerintah daerah menggunakan model delone dan mclean. Jurnal Akuntansi Dan Investasi, 13(1), 28-34.

Aziati, Y. (2020). Analisis Pengaruh User Experience Terhadap Kepuasan Pengguna Mobile Application E-Commerce Shopee Menggunakan Model Delone \& Mclean (Issue Januari 2020).

I.Chailis, I. A. A. N. (2019). Faktor-Faktor Yang Mempengaruhi Masyarakat Menyalurkan Donasi Melalui Platform Crowdfunding Berbasis Online. Jurnal Syarikah, 5(1), 94108.

kitabisa.com. (2018). About Us. Kitabisa. https://kitabisa.com/about-us

Nugroho, A. Y., \& Rachmaniyah, F. (2019). Fenomena Perkembangan Crowdfunding Di Indonesia. Jurnal Ekonomi Universitas Kadiri, 4(1), $\quad 34$. https://doi.org/10.30737/ekonika.v4i1.254

Saputro, P. H., Budiyanto, D., \& Santoso, J. (2016). Model Delone and Mclean Untuk Mengukur Kesuksesan E-Government Kota Pekalongan. Scientific Journal of Informatics, 2(1), 1-8. https://doi.org/10.15294/sji.v2i1.4523

Sitanggang, M. H. A. (2018). Memahami Mekanisme Crowdfunding dan Motivasi Berpartisipasi dalam Platform Kitabisa.com. E Journal UNDIP, 23(3), 1-11.

Wisudiawan, G. A. A. (2015). Analisis faktor kesuksesan sistem informasi menggunakan model delone and mclean. Jurnal Ilmiah Teknologi Informasi Terapan, 2(1), 55-59. 